\section{Arifah Mardiningrum}

received her undergraduate degree in English Education from State Uhiversity of Yogyakarta, and her master's degree from Indiana Uhiversity of Pennsylvania. She has taught in English Education Department of Uhiversitas Munammadiyah Yogyakarta since 2012. Her teaching area indudes reading, witing, speeking, presentation (public speaking), and Second Language Acquisition. Her research interest revolves the area of creative teaching, atistic and narrative pedagogy, particularly in drama pedagogy, and Second Language Acquisition, particularly around immersion prograns.

\title{
EFL Teachers' Linguistic Self-Concept in a Study Abroad (SA) Program
}

$27-37$

\section{ABSTRACT}

The current study investigated the experiences and linguistic self-concept of six EFL teachers from Indonesia in a Study Abroad (SA) program. The participants were six EFL teachers who were in their first year of an SA program in the United States of America. All of them were enrolled as students in postgraduate programs in different universities in the U.S. when the data were collected. The data collection was conducted through semi-structured interviews through videocalls. The study found that the participants encountered linguistics experiences related to certain linguistic features and culture. In addition to those experiences, certain forms of linguistic selfconcept were also found. Participants' linguistic self-concept showed that they perceived that they were not proficient enough in English, their English was very formal, they were proficient on certa in area, and their struggle was not a unique experience. It can be concluded that as learners in an SA program, EFL teachers experienced what were normally experienced by learners in an SA program in general.

Keywords: Linguistic self-concept, study abroad, EFL teachers.

\section{INTRODUCTION}

The embassy of the U nited States in Indonesia (2014) reported that in 2014, "7,000 Indonesians [studied] in the U nited States" and that they aimed to double the number in the future (para.1). The embassy added that study abroad program is one of the ways to maintain bilateral relationship between the two countries. The opportunity to study abroad is offered through scholarship programs by pri- 
vate and government foundations such as Fulbright, a scholarship program sponsored by the U.S. government, and DIKTI (Indonesian Directorate of $\mathrm{H}$ igher Education) scholarship, sponsored by the Indonesian government. For teachers, this program is hoped to be the space for quality improvement (Kemendikbud DIKTI, 2014)

Studies showed that there was indeed a room for quality improvement from an SA program. In general, SA programs have been considered as the "context for language learning" (Kinginger, 2013, p. 341). Therefore, a myriad of studies was conducted to seek for an understanding of the impacts of SA programs, especially on language skills. A few of these studies investigated participants' linguistic affordance (Allen, 2010), individual differences (Anderson, 2014), language gain/ acquisition (Baró \& Serrano, 2011; Themudo, Page, \& Benander, 2007), speaking ability (Kang, 2014), Ianguage practice (Larzén-0̈ stermark, 2011), language learning (Li, 2014; Savage \& H ughes, 2014; Sato, 2014), language proficien cy (Li, 2014; Savicki, 2011), communicative competence (Lockley, 2013), Ianguage pragmatics (Li, 2014; Reynolds-C ase, 2013; Shively, 2011), and language identity (Sato, 2014) to name a few.

However, all of the above studies focused on investigating students, instead of teachers, which seemed to be the trend of scholarly studies in this area. In absence of studies focusing on teachers, there is a necessity to conduct a study in this area. W hat makes teachers might have a unique experience in an SA program is that they are both teachers in their home country, and students in the host country. In addition, SA programs for them are mostly intended to be a professional development project. Therefore, more studies are needed to see whether the programs have really met their vision. This idea is shared by most studies of teachers in SA programs. Of the few, the foci are on the impacts of SA programs on the teachers' professional lives (Allen, 2010), their language proficiency (Allen, 2013), their experiences of living in the target country (Bilash \& Kang, 2007), their learning context (Mora \& Roux, 2010), and their self-perception on their proficiency (Wang, 2014).

It can be concluded that there needs to be more studies on teachers in relation to SA programs they attended. For the current study, the term "self-concept" is used to seek an understanding of how teachers in their SA programs perceived their own language proficiency during their program. The term "learners" is also used to refer to the participants since in the SA program, their status is students. The study can add to the scholarship on SA programs, teacher's professional development, and the field of language teaching and learning in general. In addition, to meet the above aim, two research questions were formulated:

1. What linguistic experiences did EFL teachers encounter in their first year of their SA program?

2. How was EFL teachers' self-concept of their English proficiency as the result of the linguistic experience?

STUDY ABROAD (SA) AND LANGUAGE PROFICIENCY

Study A broad (SA) has been studied repeatedly in terms of its outcome and its process. Kinginger (2011), reviewing the bulk of research on the subject, found that, in terms of outcome, one of the mostly discussed issues is related to language gain. The foci were mostly on the "proficiency as 
operationalized in tests" and "components of communicative competence (grammatical, sociolinguistic, discourse, or strategic abilities)" (Kinginger, 2011, p. 59). Kinginger added that even though SA has been regarded as supporting improvement in language proficiency, studies show that individual differences might influence the outcome. This means that going on an SA program does not necessarily guarantee participants' improvement in the target language proficiency.

A research by Anderson (2014), for example, supported Kinginger's (2011) conclusion on the matter. The study aimed to explore the learners' individual differences in terms of cognitive and affective aptitude in relation to their oral proficiency gain in a four-week SA program. The study found that each of these learners showed diverse aptitude profiles and despite the same extensive four-week program they attended, they also showed different oral-proficiency gain. It was expected that the learners with high aptitude profile would gain more. However, in fact, it was not the case. O nestudent who showed a high aptitude profile seemed to not make a significant improvement in oral proficiency gain.

As stated by Benson, Barkhuizen, Bodycott, and Brown (2013), SA programs are not only aimed at the "improvement of language skills," but they also "include enhanced personal independence, intercultural competence, and academic knowledge and skills" although many studies seem to indicate that it was not al ways the case (p.36). In fact, all participants in the current study were in a scholarship program, which is "available to Indonesian citizens to undertake graduate degree study or advanced research at a US university in a variety of fields" (AMINEF, 2017, para.1). This implied that target lan guage proficien cy improvement is not the main goal, especially when the program itself requires a high level of target language proficiency of its participants prior to the program.

In her analysis on studies on SA programs, Kinginger (2011) found that the studies conducted quantitatively have proven that SA programs, have a significant correlation to their participants' linguistic gain regardless of the individual differences. H owever, as Kinginger (2011) reviewed, some case studies and ethnographic studies on SA programs revealed that "learning in study abroad is a complex, dialogic, situated affair in which the subjectivities of students and hosts are deeply implicated" (p.64). This means that there are many factors in an SA program needed to see to understand the process of learning during the program. For example, although two SA students experienced similar lin guistic insecurity, their interaction with the host family and the way the host family treated them could shape a different perception about the target language (Kinginger, 2011). As a result, the language gain might also be different. This underlines the necessity to understand more deeply the experience of each individual and how they perceive that experience.

\section{LINGUISTIC SELF-CONCEPT AND SA}

M ercer (2011) states that self-concept "consists of the beliefs one has about on eself, one's self-perception" which are not necessarily facts, but more of "what one believes to be true about oneself" (p.14). In the current study, M ercer's term, Foreign Language Learning (FLL) is also suitable to refer to what the study aims to investigate. M ercer defines it as "an individual's self-descriptions of competence and evaluative feelings about themselves 
as a Foreign Language (FL) learner (p.14). M eanwhile, using the term "linguistic self-concept", Benson, Barkhuizen, Bodycott, and Brown (2013) state that it refers to "how participants perceive themselves as second language learners and users (their reflexive identities), and the projection and recognition of imagined identities in the study abroad context" (p.80). Summarizing from these definitions, the current study uses the term selfconcept in English proficiency to describe the participants' perception on their linguistic experiences and how they perceive their proficiency in English based on their evaluation or reflection on those experiences.

Reviewing from arrays of studies on Foreign language learner's self-concept, M ercer (2011) concludes that there is an extremely complex process influencing the formation of a learner's self-concept and that this implies that "there is a need to be careful not to overestimate the potential effectiveness of educational approaches that aim at enhancing global self-concept or self-esteem" (p.167). In other words, when talking about a learner's selfconcept, the uniqueness of each individual should be regarded. M ercer (2011) adds that even though this means that self-concept is very unpredictable and there is no exact solution to influence a learner's language self-concept, a non-threatening learning situation can be endeavored to give positive influence to the learner's foreign language selfconcept. The challenge is; therefore, lays on the teachers in that learning environment since they need to maintain in mind that each student has his/ her own complex and personal foreign language self-concept and that many factors influence that concept (M ercer, 2011).

In an SA program, self-concept can be influ- enced by various factors. Wang (2014), investigating the self-perception of EFL teachers on their language proficiency, found that the group of teachers who had stayed longer in an SA program tended to perceive their language proficiency improvement more highly than the one having stayed in a shorter time (six months). This shows that the length of time spent in an SA program influences the way its participants perceive their language proficiency. However, it is too fast to conclude that time is the only factor influencing someone's linguistic self-concept. Social interaction and environment where SA participants interact with others will al so play a sign ificant part. It is relevant to borrow Aveni's (2005) idea that in an SA program, "Learners gather information about their sense of status, control, safety, and validation in an $\mathrm{L} 2$ interaction from multiple sources" (p.55). Aveni (2005) added that the sources might come from "social-environmental cues" and "learner-internal cues" (p.55). The former refers to the factors such as interlocutors' behavior, characters, age, genders, etc., while the former refers to the learner's attitudes and beliefs about themselves, their foreign language ability, etc.

Another conclusion that can be drawn from studies of self-concept in an SA program is that self-concept is dynamic. Aveni (2005) argues that in a program such as SA, participants "often re port feeling as if those around them may perceive them to be unintelligent, lacking personality or humor, or as having the intellectual development of a small child" (p.9). This might be the result of what they believed about accents, grammar, intonation, or any linguistic system that they believed they should have to be addressed as proficient. H owever, Aveni (2005) added that, in her rigorous 


\section{1}

Journal of Foreign L anguage Teaching \& L earningV ol.2 N 0.2 July 2017

analysis of several SA participants in her study, that after certain length of time and more experience, these learners gained a better perception about their language ability and became less risk averse in using the target language. The finding of a naturalistic study by Allen (2013) to several teachers in an SA program corroborates to this notion. $U$ sing the teachers' diaries, Allen found several points showing how the teachers perceived their language proficien cy. 0 ver time, these teachers, among others, believed that it is alright to not always understand all levels of the language and that language proficiency is a long process.

\section{METHODOLOGY}

This qualitative study was conducted to six Indonesian EFL teachers who had spent approximately one year of SA programs in the U nited States of America (USA). All of them were under the same scholarship scheme and were English teachers in Indonesia with a variety of experience of teaching students of different ages and institutions (school and university). All of them speak Bahasa Indonesia and have different vernaculars. O ne participant took a doctoral degree program, and the others took a master's degree program. They took programs under the area of Teaching English for Speakers of 0 ther Languages (TESO L) and Applied Linguistics. Prior to the program, to compete for the scholarship grant and to be enrolled in the university of their choice, these teachers were required to take an English proficiency test in the form of Internet-Based Test of English as a Foreign Language (TOEFL IBT) and they had to achieve the score required by the scholarship grantor and the university. In this study, some participants refused to mention their score, but the fact that they were granted the scholarship and were enrolled in one of the universities in USA showed that they had reached the score for an advanced EFL users and were considered by the scholarship grantor as capable to survive the academic life in the host country.

The data collection was conducted after the current study had been reviewed by the Institutional Review Board (IRB), and participants had signed the consent form. The data were collected through semi-structured interviews using English as the medium of communication. Because all participants lived in different states, the interviews were conducted online through video-calls. The interviews were recorded with the consent from the participants. The recorded interviews were then transcribed and coded. The coding process was conducted by first scrutinizing the data to collect the parts containing the foci of discussions, namely the participants' experiences and linguistic self-concept. The next step was to scan the trends or overlapping phenomena, which then became the base for categorization of the findings. The categorized findings were then analyzed and related to past literatures.

I need to inform that my positionality might encourage bias in my analysis of the data. At the time of data collection, I shared identities with the participants. I was al so a grantee of the same scholarship as the participants. I am also an EFL teacher in Indonesia and was a TESO L master's student in a university in the U SA. In addition, I al so shared the same L1 with some participants and speak Bahasa Indonesia, the national language of the Republic of Indonesia. These shared identities might contribute to certain personal view, which 
might influence my analysis.

\section{FINDINGS}

\section{LINGUISTIC EXPERIENCES}

The current study focuses on six EFL teachers' experiences in an SA program in the USA. The data showed that all participants experienced the struggles when interacting with other interlocutors. The struggles were caused by some linguistic features and by cultural aspects.

Struggle caused by linguistic features. All six participants stated that they had classmates or friends of various origins and nationalities (commonly called international students). They stated that at times, they felt that they could not understand their fellow international students in a communication. They mentioned that the causes were mostly around linguistic aspects such as accents, intonation, pronunciation, and different styles of English. The following excerpt from Participant 2 showed the struggle.

"M y only problem is to understand their words. I got

friends from China and Saudi Arabia who speak

[English]. I don't understand them because of their pronunciation" (R2.C 2.23).

The thought of accent as one factor that hindered understanding was also shared by Participant 4 , referring to accents of other international students, and Participant 6, referring to her English native speaker professor. Participant 5 , on the other hand, focused more on the different style of English that she encountered as the factor to cause her struggle.

"At first, it's quite difficult when we talked about spoken English. Spoken English is varied in the U S. It depends on the context. It depends on the place where English is used, and it depends on the age of the speakers. So, when I wastalking with undergraduate students, the spoken language is different from the graduate students because most undergraduate students are still young, and they just graduated from senior high school. They used nonformal English that sometimes I didn't understand. But I'd ask what he or she means and they would explain it to me" (R5.C2.06).

Participant 4 added that pronunciation had al so caused communication struggle, but this time, she referred to her own pronunciation.

"M ay be because of this pronunciation. When I talk to people - I forget if they're A mericans or not - they didn't understand me, so I think I speak okay. So, I need to revise, rearrange all my words and practice again" (R4.C 2.02).

Further, she explained that this experience made her less confident in speaking because such thing never happened when she was in Indonesia.

Struggle caused by cultural aspects. The interviews with the participants also revealed that some of the struggles were caused by different cultural backgrounds of theirs and other interlocutors. Participant 2, for example, stated that he encountered an experience where he felt lost with the conversation and humor in the classroom. He explained it in the following excerpt.

"M y classmates are very friendly and they like joking, but they like joking in A merican ways, which makes me uncomfortable" (R2.C2.15).

"For me it's not funny" (R2.C 2.21).

Participant 3 also shared her struggle in understanding people from different countries or different cultural background as follows. She mentioned that it was difficult for her to understand other students from different countries other than U S because they "don't really share the same under- 
standing behind" English (R3.C2.02). She explained what she meant by that different understanding as follows.

"W hen, for example, I talk to a Japanese, even if he's not a native speaker, we both arenot native speakers, we do not have the connection. The only connection we have is that we are not native speakers. But when we speak English, we should try to figure out what I mean and what he means" (R3.C 2.04).

Both cases above show that sometimes, the struggle was not about to speak the language. It lied on the meaning of the spoken language in which interlocutors from different cultural backgrounds might understand it differently.

\section{LINGUISTIC SELF-CONCEPT}

After several experiences of struggling and surviving communications in an SA context for one year, participants showed their linguistic self-concept as follows.

I am not completely proficient in English. All participants were basically quite confident with their English proficiency prior to their departure to the US as they said in the beginning of their interview. However, after encountering several experiences of struggle, most participants showed a little bit sense of inferiority regarding their English proficiency. Participant 2 expressed it in the following excerpt.

"W hen I spoke in the discussions [in class], for example, I was not very confident in giving my ideas although I had a good idea. I was worried that the way I explained or the way I delivered ideas were not very well managed or well organized. Therefore, I spoke very slowly" (R2.C 2.12).

"I thought too much, which hindered me from speaking. M ay be, I was just worried they didn't under- stand what I said" (R2.C2.13).

Interestingly, Participant 2 stated that this feeling of inferiority only occurred when he had to interact with his American counterparts but not with other international students. Similarly, Participant 5 shared her lack of confidence of her proficiency in certain topics of conversation rather than issues pertaining to certain linguistic features or language skills. Participant 1 , on rather different take, shared her perception that she lacked proficiency in a certain language skill. She mentioned academic written English as her weakness.

"In academic life, I don't think I'm proficient enough because there are linguistic features I'm not quite familiar yet, and I don't feel like I have used that properly. So, to me, in some cases, I feel I'm quite proficient, but in academic, I might be improving, but I don't feel like I'm proficient enough yet" (R1.C 4.02).

Participant 5, al so mentioned specific area where she felt not as proficient after one year of studying in the US. She stated as follows.

"I think, in terms of grammar, I don't make much improvement because I feel that my grammar is still the same as previous years" (R5.C 4.02).

My English is very formal. Two participants mentioned that they believed that the English that they used was different in that they felt that their English was very formal or standard even when they used it in an informal situation. Participant 2 , for example, stated that he felt that he spoke "very formally" and felt like "a textbook" (R2.C 2.02).

Participant 5 also felt that her English was formal.

"W hen I came here, there was a lot of differences. If we talk about other languages, I think, in Indonesia, we mostly learned academic writing. But when we 
came here, we heard people talking in English informally. And even in a formal [situation], they also insert some informal conversation, informal things" (R5.C 2.04).

I am proficient in certain area. W hether the experiences sound negative or positive, all participants seemed to take something positive from them. They showed confidence on their English proficiency. Some participants perceived that their English was good enough, at least for an oral communication. Participant 3, for example, believed that her English was adequate for communication need.

"Even if I'm not perfect, these days, I can still communicate. I can survive a year in this state, so may be, I'm proficient enough" (R3.C 4.03).

This idea was also shared by Participant 1 and 4. In addition, Participant 4's confidence was al so a result of comparing her proficiency to her peers. She expressed that after a while, she convinced herself to be confident because she was still learning and that she found out that many people struggled with communicating too (R 4.C 4.01). She added as follows.

"I mean, I find several friends from other countries outside U .S. speak English, but I feel I'm better. So, I feel like "W hy should I be discouraged?" (R 4.C 4.03).

This idea of comparing self to peers is also implied by Participant 2. Participant 5, slightly different from the rest, felt that she was confident in the area of academic English. She stated as follows.

"I would say that perhaps, I'm good at academic English, especially when somebody asked me to write a paper. It doesn't mean that my writing is qualified for publication. [W hat I mean is that] when I do academic writing or academic talking, I can do bet- ter" (R5.C 4.08).

This likely came from her experience of struggling to cope with the topic of conversation outside classroom as she shared in the interview.

$M$ y struggle is not unique. The last category of participants' linguistic self-concept is related to their understanding that their experience was not something that they uniquely experienced. Their occasional struggle to understand what other international students seemed to make them learn that they, were not the only one with linguistic boundaries, but also their counterparts, regardless their nativity. They showed more acceptance to their condition. Participant 6, for example, believed that accent was not an issue in communication.

"I would say that everybody, whether he is the socalled native speaker, or the so-called native speaker of English will definitely have accent. That's what I learn about accent. I used to think that those coming from countries where English is spoken as the mother tongue, are free from accents. N ow, here I find that everybody, wherever she/ he comes from, will have particular accent. I believe that accent is part of one's identity to not necessarily to get the rid of" (R6.C 2.04).

Participant 1, in addition, believed that everybody also struggles, at some point, in communication. She also mentioned her view on native speakers.

"N ow I camehere, I realized that it doesn't only happen to non-native speakers like us. I realized that even my native speaker friends, they also sometimes face the kind of situation when we have to be able to find a way out of the communication trouble by using our strategic competence" (R1.C 2.02).

Each of the category of self-concept above was 
not always shared by all participants. However, there seemed to be a trend that the experiences involving people in the participants' academic life played a part in their linguistic self-concepts although it might only be implied.

\section{DISCUSSION}

It can be concluded from the findings that the experiences of all participants took place when they interacted with the people in their academic environment. Although in the interview, I never asked specifically about their academic life, the participants' responses were mostly related to their interaction with their peers. This phenomenon is not unique. Aveni (2005) stated that "learners set expectations for their own performance based on the presentations of others and look to other students who seem to perform better or worse than they [do] and shift their attitudes toward themselves accordingly" (p.91). In line with this, M ercer (2011) argued that this attitude of comparing oneself to peers becomes the "external frame of reference" in the formation of self-concept among learners (p.128). The participants of the current study, despite their status as teachers back home, were learners in their SA program. Therefore, the tendency to act like learners in general seems to be reasonable. Further, M ercer (2011) added that the comparison is usually done to peers that learners consider as holding similarities so that it will suggest a reasonable comparison. This was al so the case with the six teachers who became the participants of this study. The finding suggests that they tended to compare themselves to other international students or other non-native speakers of English, most likely because for these international students, English is also a foreign language. There was also a mention of native speakers of English, but the context was still around classroom, which means that the peers compared still shared certain similar identity.

A nother conclusion that can be made is that participants' experience and their self-concept about their English ability came from the struggles that they experienced or they perceived as being experienced by their peers. Such struggles are commonly experienced by participants of an SA program as a result of being "stripped of the comfortable mastery of their first language and of cultural and societal adroitness" (Aveni, 2005, p.9). The struggles also mostly pertained to linguistic features such as pronunciation, accent, and style. In this sense, according to Aveni (2005), an SA environment can contribute to the participants' inferiority. H owever, although all participants experienced certain struggles, each perceived their experience in their own way. N ot all participants felt clear inferiority. In fact, in the end, all participants' self-concept tended to be positive. Aveni mentioned three factors that might be the explanation as to despite the negative experience that the participants had, they still showed self-affirming attitude that they actually made improvement. This attitude might take place because the participants' "internal cues are positive", they had the "wish to elevate their internal sense of security," and "the importance of their communication goal outweighs their need to maintain their security" (Aveni, 2005, p.118).

\section{CONCLUSIONS AND SUGGESTIONS}

To sum up, the teachers' linguistic self-concept in general revolves around the success in communicating with people from different background and in any given situation. Their experiences are 
commonly experienced by learners in any SA program. W hat is interesting is that there was a growing empathy to other speakers after they were exposed to the reality that English is not only as modeled by what they considered as native English speakers.

I think it is safe to say that SA programs gave the benefit of professional development to a teacher in a way that it can be the space to reflect and learn about their own competence. Although there has been a common belief that SA program is beneficial, at certain sense, it is still considered as an exclusive program which is only available for teachers in certain level of education. Therefore, more socialization on various SA programs is needed to encourage more teachers.

\section{REFERENCES}

Allen, H . (2010). Interactive C ontact as Linguistic Affordance during Short-Term Study Abroad: Myth or R eality?. Frontiers: The Interdisciplinary Journal of Study A broad, 19, 1-26.

Allen, L. Q . (2010). The impact of study abroad on the professional lives of world language teachers. Foreign Language A nnals, 43(1), 93-104.

Allen, L. Q . (2013). Teachers' beliefs about developing language proficiency within the context of study abroad. System, 41(1), 134-148.

AMINEF. (2017). Fulbright scholarships. Retrieved from https:/ / www.amin ef.or.id/ grants-forindonesians/ fulbright-programs/ scholarship/

Anderson, S. L. (2014). Individual differences \& study abroad: four profiles of oral proficiency gain. Journal of L anguage Teaching and Research, 5(3), 477-486.

Aveni, V. A. P. (2005). Study abroad and second language use: $C$ onstructing the self. Cambridge U ni- versity Press.

Baró, À. L., \& Serrano, R. S. (2011). Length of stay and study abroad: Language gains in two versus three months abroad. Revista E spañola de L ingüística A plicada, (24), 95.

Benson, P., Barkhuizen, G., Bodycott, P., \& Brown, J. (2013). Second language identity in narratives of study abroad. England: Palgrave M acmillan.

Bilash, 0., \& Kang, J. (2007). Living well in a changing world: W hat Korean teachers of English say about a study abroad program in C anada. The Journal of E ducational T hought (JET)/ Revue de la Pensée E ducative, 295-309.

Kang, D. M. (2014). The effects of study-abroad experiences on EFL learners' willingness to communicate, speaking abilities, and participation in classroom interaction. System, 42, 319-332.

Kementrian Pendidikan dan Kebudayaan, Direktorat Jenderal Pendidikan Tinggi. (2014). Beasiswa luar negeri. Retrived from http:/ / dikti.go.id/ informasi-beasiswa/ beasiswa-luarnegeri/ ?lang=id

Kinginger, C. (2011). Enhancing language learning in study abroad. A nnual review of applied linguistics, 31, 58-73.

Kinginger, C . (2013). I dentity and language learning in study abroad. Foreign Language Annals, 46(3), 339-358.

Larzén-Ö stermark, E. (2011). Intercultural sojourns as educational experiences: $A$ narrative study of the outcomes of Finnish student teachers' language-practice periods in Britain. Scandinavian Journal of Educational Research, 55(5), 455-473.

Li, L. (2014). Language Proficiency, Reading Development, and Learning C ontext. Frontiers: the Interdisciplinary Journal of Study A broad, 24, 7392. 
Li, S. (2014). The effects of different levels of linguistic proficiency on the development of $L 2$ $C$ hinese request production during study abroad. System, 45, 103-116.

Lockley, T. (2013). Exploring self-perceived communication competence in foreign language learning. Studies in Second L anguage L earning and Teaching, (III-2), 187-212.

Mercer, S. (2011). Towards an understanding of language learner self-concept (Vol. 12). Springer Science $\&$ Business M edia.

Mora, A., Roux, R., Arredondo, F., \& Victoria, C. (2010). Mexican Teachers of English Studying Abroad: Their Perceptions of Their Learning Contexts Profesores universitarios mexican os de lengua inglesa en el extranjero: percepciones de sus contextos de aprendizaje. Revista E lectrónica de Investigación Educativa, 12(2), 2.

Reynolds C ase, A. (2013). The Value of Short Term Study Abroad: An Increase in Students' C ultural and Pragmatic $\mathrm{C}$ ompetency. Foreign Language Annals, 46(2), 311-322.

Sato, T. (2014). The Effects of Study Abroad on Second Language I dentities and Language Learning. Turkish 0 nline Journal of $Q$ ualitative Inquiry, 5(3), 28-41.

Savage, B. L., \& H ughes, H. Z. (2014). H ow D oes Short-Term Foreign Language Immersion Stimulate Language Learning?. Frontiers: the Interdisciplinary Journal of Study A broad, 24, 103-120.

Savicki, V. (2011). Relation ship of Foreign Lan guage Proficiency to Study Abroad O utcomes and Inputs. F rontiers: The Interdisciplinary Journal of Study A broad, 21, 63-85.

Shively, R. L. (2011). L2 pragmatic development in study abroad: A longitudinal study of Spanish service encounters. Journal of Pragmatics, 43(6), 1818-1835.

Themudo, D., Page, D., \& Benander, R. (2007). Student and faculty perceptions of the impact of study abroad on language acquisition, culture shock, and personal growth. AURCO Journal, 13, 65-79.

U .S. Embassy and C onsulates in Indonesia. (2014). Study in the U.S. Retrieved from http:/ / jakarta.usembassy.gov/ study.html

Wang, D. (2014). Effects of study abroad on teachers' self-perceptions: a study of Chinese EFL teachers. Journal of Language Teaching and $R e$ search, 5(1), 70-79. 